\title{
Eksistensi Dā'iyah di Tengah Domestikasi Citra Diri Perempuan Shalihah: Perspektif Feminis Eksistensialis
}

\author{
Faridatus Sholihah \\ Program Magister Kajian Wanita \\ Universitas Brawijaya, Malang \\ email: faridatus.sos@gmail.com
}

\begin{abstract}
Being an empower women by actively showing her existence in the publicity is not easy. Moreover when it is related to leadership in the religion issues, where it is still dominated by men. This study aims to describe the existence that is fought by da'tiyah in the public space, whereas social construction holds them with domestication. This research uses descriptive qualitative methods. Techniques of collecting data by an in-depth interview, and validating by triangulation. The results show that "shalihah" concept is still closely related to domestic works, while the "imam" concept in the religion is still understood as a status that must be played by men. The criteria by sex are still in line with the quality of da'wah materials, da'wah methods, or even the knowledge of the missionary. So, dā'iyah feels a dilemma in carrying out their roles in the public and domestic space. For this reason, various strategies have been carried out by dā'iyah to maintain their existence.
\end{abstract}

Keywords: dā'lyah; domestication; existence; shalihah women

\begin{abstract}
Abstrak: Menjadi wanita yang berdaya dengan secara aktif menunjukkan keberadaannya di ruang publik tidaklah mudah. Apalagi ketika itu terkait dengan kepemimpinan dalam masalah agama yang masih didominasi oleh laki-laki. Penelitian ini bertujuan untuk menggambarkan eksistensi yang diperjuangkan oleh dā'iyah di ruang publik, sedangkan konstruksi sosial menahan mereka dengan domestikasi. Penelitian ini menggunakan metode kualitatif deskriptif. Teknik pengumpulan data dengan wawancara mendalam, dan validasi dengan triangulasi. Hasil penelitian menunjukkan bahwa konsep "shalihah" masih terkait erat dengan pekerjaan rumah tangga, sedangkan konsep "imam" dalam agama masih dipahami sebagai status yang harus dimainkan oleh laki-laki. Kriteria berdasarkan jenis kelamin masih sejalan dengan kualitas materi dakwah, metode dakwah, atau bahkan pengetahuan misionaris. Jadi, dā'iyah merasakan dilema dalam menjalankan peran mereka di ruang publik dan domestik. Untuk alasan ini, berbagai strategi telah dilakukan oleh dā'iyah untuk mempertahankan keberadaan mereka.
\end{abstract}

Kata Kunci: dā'iyah; domestikasi; eksistensi; perempuan shalihah 


\section{A. Pendahuluan}

Laki-laki dibentuk oleh budaya untuk menjadi pemilik kehidupan, sedangkan perempuan hanya sebagai pengikutnya. ${ }^{1}$ Akar patriarkat yang sudah menjalar dengan sangat kuatnya ini terjadi hampir pada sebagian besar masyarakat dunia. Cita-cita gerakan feminis yang hendak membawa perubahan pada harkat martabat perempuan sebagai manusia layaknya laki-laki sampai hari ini pun belum mencapai keberhasilan yang maksimal. Apalagi ideologi ini sering dihadapkan dengan gerakan fundamentalis keagamaan yang menganggap bahwa feminis sebagai ideologi yang perlu diperangi dengan dalil-dalil penuh hegemoni kepentingan.

Dikenal sebagai masyarakat Timur, Indonesia menjadi terlabeli untuk menunjukkan kuatnya nilai kultur dan agama yang dipegangnya. Namun, kultur dan tafsir agama yang dipegang teguh merupakan hasil akulturasi dengan nilai-nilai patriarki yang mendisposisikan perempuan. Perempuan Indonesia, terutama muslimah, menjadi tertuntut untuk mencapai figur perempuan beradat Timur yang shalihah menurut versi stereotipe patriarkat. Bagaimana perempuan harus lemah lembut, sopan santun, lemah gemulai, diam, berlindung di belakang lakilaki, spesialis urusan domestik, dan tentu saja perempuan pingitan. Apalagi agama menjanjikan surga tertinggi bagi perempuan yang mampu bersabar dalam menghadapi takdir keperempuanannya. Sampai hari ini perempuan yang mampu berekspresi di ranah publik, berkarier, memberdayakan orang lain, dan memimpin suatu komunitas masih dianggap sebagai perempuan yang keluar dari kodratnya dan merebut peran yang seharusnya dimiliki oleh kaum laki-laki. ${ }^{2}$ Aturan yang tidak tertulis tersebut dilegitimasi oleh tafsiran agama dan adat yang memposisikan laki-laki sebagai imām, sedangkan perempuan hanya sebagai $m a^{\prime}-$ mūm. Apalagi dalam hal urusan keagamaan, dimana laki-laki masih selalu menjadi pusat kepemimpinan. Hal ini jugalah yang membuat jumlah juru dakwah laki-laki dan ulama laki-laki selalu masih lebih banyak dibandingkan dengan juru dakwah dan ulama perempuan.

Penelitian ini bertujuan untuk mendeskripsikan bagaimana seorang perempuan juru dakwah (däizyah) sebagai salah satu representasi dari ulama dan

${ }^{1}$ Nawal El Saadawi, Perempuan dalam Budaya Patriarki (Yogyakarta: Pustaka Pelajar, 1997), 23.

${ }^{2}$ Candace West and Don H. Zimmerman, "Doing Gender," Gender and Society 1, no. 2 (1987): 125-51, https://www.glaac.uk/0t4/crcees/files/summerschool/readings/WestZimmerman_1987_DoingGender.pdf 
pemimpin perempuan dalam beragama mampu mempertahankan eksistensinya. Berbagai macam hambatan dan rintangan yang dihadapinya tetap mampu membuatnya bertahan dan memilih menjadi seorang dā'iyah. Figur perempuan shalihah yang digaungkan oleh banyak penafsiran patriarkat direinterpretasi sehingga mereka juga memiliki dasar dalam berdakwah.

Salah satu jalan untuk meraih kesetaraan adalah dengan upaya memunculkan eksistensi perempuan sebagai makhluk yang sama derajatnya seperti laki-laki. ${ }^{3}$ Sejalan dengan itu pengaruh sejarah yang telah mengakar kuat harus segera didekontruksi agar eksistensi manusia kembali pada makna kehidupan manusia itu sendiri. Laki-laki dan perempuan, begitupun femininitas dan maskulinitas hanya merupakan sebuah keberagaman identitas. Penghapusan stereotipe pada salah satu pengsifatan jenis kelamin merupakan salah satu agenda utama sebelum perjuangan keadilan, hak dan tanggungjawab. ${ }^{4}$

Beauvoir menyusun empat strategi dalam memperkuat eksistensi perempuan yaitu dengan memasuki dunia publik, memperdalam kemampuan intelektual, berusaha mencapai transformasi sosial dan menolak internalisasi menjadi makhluk kedua. Usaha ini akan sangat efektif ketika laki-laki bersedia membuka pikirannya untuk menurunkan ego, dan perempuan sadar untuk meningkatkan eksistensinya. Memasuki ruang publik menjadikan perempuan semakin percaya diri dalam menampilkan eksistensi keberadaannya. Bukan merupakan prioritas tentang jenis pekerjaan apa yang akan diambil oleh perempuan tersebut, karena dengan bekerja di ruang publik, perempuan akan mengenal dan dikenal oleh lingkungan di luar rumahnya. Sedangkan memperdalam kemampuan intelektual akan semakin menambah nilai kualitas diri dalam menyokong keberadaannya di ruang publik. Perempuan dengan intelektualitas yang tinggi akan semakin dihormati dan perhitungkan eksistensinya. Hal ini akan semakin mendorong perempuan untuk selalu termotivasi dalam melakukan transformasi sosial tanpa terpengaruh oleh nilai-nilai di luar keyakinannya yang dianggap justru menghambat transformasi itu sendiri. Sehingga, perempuan akan sama sekali menolak diinternalisasi sebagai makluk

\footnotetext{
${ }^{3}$ Simone DE. Beauvoir, Second Sex: Fakta dan Mitos (Yogyakarta: Pustaka Promethea, 1989). 17.

${ }^{4}$ Rosemarie P. Tong, Feminist Thought: Pengantar Paling Komprehensif kepada Arus Utama Pemikiran Feminis (Yogyakarta: Jalasutra, 1998), 31.
} 
kedua ketika ia sadar dan bisa membuktikan bahwa ia juga sama mampunya dengan jenis kelamin lain dalam memerdekakan eksistensi kehidupannya.

Penelitian ini menggunakan metode desekripif kualitatif. Pengumpulan data dilakukan dengan in-depth interview yang dilaksanakan bersama 5 orang dā'iyah secara terpisah, dengan kualifikasi partisipan sebagai berikut: 1) dā'iyah yang bersedia menjadi partisipan dalam penelitian ini, 2) daiyah yang telah lebih dari 10 tahun menjadi seorang juru dakwah, 3) dā'iyah yang masih tetap eksis memberikan ceramah kepada jama'ah laki-laki maupun perempuan.

\section{B. Memilih Menjadi Seorang Dä'iyah}

Setiap perempuan akan selalu dihadapkan pada tantangan "motherhood" oleh masyarakat. ${ }^{5}$ Di manapun lingkungan budayanya, seorang perempuan akan dilekatkan dengan peran dan tugas sebagai pengasuh dan pendidik bagi anak-anaknya. Hal ini bukan merupakan bahan perdebatan lagi karena "motherhood" adalah sebuah fitrah untuk merasakan kasih sayang terhadap anak-anak yang telah dikandung dalam rahimnya dan yang telah disusuinya. Bahkan binatang yang tidak berakal pun memiliki insting motherhood kepada anak-anaknya. Hal ini tidak mengherankan karena Tuhan menciptkan insting untuk menyayangi anak-anak kepada semua makhluk, termasuk laki-laki. Motherhood adalah kekuatan untuk merasakan dan bersikap menjadi seorang ibu bagi anak-anaknya. Rasa dan sikap tersebut terwujud dalam kasih sayang, melindungi, merawat, mendidik, dan menjamin keamanan anak-anaknya. Kekuatan untuk menjadi seorang ibu bukan berarti harus menjadi seorang ibu terlebih dahulu. Perempuan yang tidak memiliki keturunan pun bisa memiliki rasa motherhood. Bahkan, laki-laki ataupun seorang ayah juga bisa memiliki kekuatan untuk berperan menjadi seorang ibu bagi anak-anaknya. Namun, yang menjadi permasalahan adalah motherhood selalu diidentikkan hanya pada perempuan kemudian dibebankan sebagai tanggungjawab utama perempuan, bahkan tidak jarang dijadikan sebagai penghalang perempuan untuk maju ke ranah publik. 2005), 11

${ }^{5}$ Kathleen Kendall Tacket, The Hidden Feelings of Motherhood (Amarillo: Pharmasoft Publishing, 


\section{Kepemimpinan Perempuan dalam Islam}

Kepemimpinan merupakan salah satu aspek di dalam kehidupan yang tidak luput dari pembahasan agama Islam. Di dalam al-Qur'an dan Hadis sendiri terdapat beberapa ayat dan petunjuk tentang praktik kepemimpinan di dalam idealitas Islam. Kepemimpinan di dalam Ayat-ayat al-Qur'an bisa dijumpai dalam QS. Āli 'Imrān: 28, QS. al-Nisā':138-139, 144, QS. al-Māidah: 51, 57, QS. alTaubah: 23, QS. al-Mujādalah: 22, dsb. Kesepakatan para ulama di Indonesia membolehkan siapapun sebagai pemimpin dengan catatan syarat yaitu beriman dan bertakwa, berintegritas yang kuat, memiliki kemampuan memimpin, dan akhlaknya bisa menjadi panutan masyarakat. ${ }^{6}$ Namun, implementasinya adalah jumlah pemimpin agama berjenis kelamin perempuan dalam hal ini adalah jumlah dä'iyah lebih sedikit dibanding dengan banyaknya jamaah perempuan yang tentu membutuhkan tafsiran perempuan dalam memahami agamanya.

Di dalam Islam sendiri, dalam memutuskan hukum dari segala sesuatu harus memenuhi syarat-syarat maqāsisid al-shari'ah (tujuan ditegakkannya hukum). Terdapat banyak pendapat dari beberapa pakar hukum Islam, di antaranya seperti dalam buku Keadilan Gender dalam Islam ${ }^{7}$ Prinsip-prinsip dasar yang digunakan dalam sebuah hukum harus: 1) Memperhatikan kemaslahatan orang banyak. 2) Mewujudkan keadilan sosial. 3) Tidak memberatkan dan menghilangkan kesulitan. 4) Universal dan dinamis. 5) Elastis dan fleksibel. 6) Ta'aqquli (al-Qur'an-Hadis) dan Ta'abbudi (konsensus masyarakat ulama).

Di dalam al-Qur'an sendiri telah banyak disebutkan mengenai prinsipprinsip kesetaraan gender sebagai sumber pertimbangan dalam memutuskan segala permasalahan hukum dan kebijakannya. ${ }^{8}$ Prinsip-prinsip tersbeut di antaranya: 1) Laki-laki dan perempuan sama-sama sebagai hamba Allah, tidak ada perbedaan status dan derajat. ${ }^{2}$ 2) Perempuan dan laki-laki memiliki

${ }^{6}$ Siti Musdah Mulia, Muslimah Reformis (Bandung: Mizan Pustaka, 2004), 72.

${ }^{7}$ Qurrotul Ainiyah, Keadilan Gender dalam Islam (Malang: Intrans Publishing, 2015), 102. 97.

${ }^{8}$ Mufidah Cholil, Psikologi Keluarga Islam Berwawasan Gender (Malang: UIN Maliki Press, 2008),

${ }^{9}$ QS. al-Dhāriyāt: 51,56 . 
kesempatan dan kemampuan yang sama dengan laki-laki untuk menjadi hamba yang ideal menurut al-Qur'an..$^{10}$ 3) Laki-laki dan perempuan sama-sama ditunjuk sebagai khalifah di bumi untuk mengelola sumber daya sebaik-baiknya. 4) Keduanya diwajibkan mempertanggungjawabkan amal perbuatannya tanpa memandang jenis kelamin. 5) Keduanya saling mengembangkan keturunan dan saling melengkapi dan saling membutuhkan. ${ }^{11}$ 6) Laki-laki dan perempuan berpotensi meraih prestasi secara maksimal. ${ }^{12}$

Dengan merujuk pada dasar dan prinsip-prinsip hukum di atas, maka sebenarnya perempuan memiliki hak dan kesempatan yang sama untuk maju menjadi dā'iyah demi kemaslahatan peradaban. Siapapun yang berdakwah, dari golongan dan jenis kelamin apapun, selama memiliki kapasitas lebih, kemampuan, ilmu, iman, taqwa, serta memiliki akhlak yang mampu dijadikan sebagai teladan, maka dia layak dijadikan sebagai pemimpin.

\section{Dilema dalam Sebuah Konsep Sholihah}

Muslimah Indonesia di era pascakolonial saat ini masih tengah memperjuangkan hak-hak kesetaraan atas akses publik yang masih didominasi oleh laki-laki. ${ }^{13}$ Sedangkan masyarakat dunia Barat, urusan distribusi akses sudah terlampaui dan sudah menekankan pada persaingan kualitas kinerja di ruang publik. Ketika perempuan merasa layak untuk maju ke ruang publik, maka akan timbul berbagai macam persoalan dan ketakutan yang akhirnya membuat hal tersebut secara langsung maupun tidak menghalangi perempuan untuk mampu mempertahankan eksistensinya.

Akar dari permasalahan ini sebenarnya adalah pada eksistensi laki-laki yang berusaha untuk terus dipertahankan di atas eksistensi diri perempuan. Perempuan akan dijegal dari banyak arah ketika perempuan ingin menyamai posisi tersebut. Bagaimana perempuan ditafsirkan sebagai aib yang harus ditutupi. Keberadaannya di luar rumah dianggap hanya akan mendatangkan

\footnotetext{
${ }^{10}$ QS. al-Hujurāt: $13,49$.

${ }^{11}$ QS. al-Baqarah : 187.

${ }^{12}$ QS. Āli Imrān : 195, al-Nisā': 124, QS. al-Naḥl : 97, dan QS. Ghāfir: 40.

${ }^{13}$ Katrin Bandel, Kajian Gender dalam Konteks Pascakolonial (Yogyakarta: Sanata Dharma University Press, 2016), 9.
} 
banyak mudharat untuk dirinya dan keluarganya. Perempuan didoktrin sebagai pemberi kehidupan, yang artinya dia harus memberi kehidupan bagi anak-anak dan suaminya. Untuk itu, perempuan harus tetap berada di dalam rumah untuk senantiasa berjaga-jaga kapanpun anak-anak dan suaminya membutuhkan perannya. Eksistensi perempuan tidak lebih dari sekedar penjaga rumah yang siap menunggu untuk dipekerjakan. Dan agama meligitimasi hal tersebut sebagai sebuah pekerjaan surgawi yang sangat mulia. Mitos yang dibangun kemudian adalah tentang karakteristik perempuan yang irasional dan kompleks sehingga sulit untuk dimengerti. Untuk itu, perempuan cocok untuk dijadikan sebagai pelengkap dan penyempurna laki-laki dalam mencapai tujuannya. Diciptakan lah sebuah idealitas seorang perempuan sholihah yang harus mampu bersakit-sakit dan berkorban demi keberhasilan laki-laki.

\section{E. Perempuan Berdakwah: Sebuah Strategi dan Aksi Dekontruksi}

Jika meruntut sejarah, peran partisipasi perempuan untuk berani tampil di depan publik dan mengambil keputusan sebenarnya mulai muncul saat perempuan masuk Islam. Pergerakan perempuan mulai terlihat ketika zaman jahiliyah berakhir dengan ditandainya syiar agama Islam, kemudian perempuan dengan tegas dan berani menolak ajaran budaya nenek moyang dan memilih kabur dari rumah dan keluarganya. ${ }^{14}$ Tidak jarang ditemui para istriistri yang masuk Islam terlebih dulu dibandingkan dengan suaminya. Nabi pun selalu mendengarkan suara perempuan sebagai suara politik. Para perempuan yang masuk Islam saat itu selalu diikutkan oleh Nabi untuk berdialog, berdiskusi, aktif bertanya dan menjawab, serta dilatih mental keberaniannya untuk menghadapi perlawanan. Namun, sebuah catatan buram kembali muncul sejak abad ke-13, dimana masa kejayaan Dinasti Abbasiyah runtuh karena menurunnya kualitas dari para keturunan raja. Selir dan harem semakin banyak, budak perempuan semakin tidak bernilai harganya. Mereka hanya hidup berfoya-foya dengan gelimang kekuasaan tanpa memprioritaskan kemajuan peradaban Islam. Sistem patriarki semakin menguat dan menjadikan status perempuan kembali terpuruk.

\footnotetext{
${ }^{14}$ Haifa A. Jawaad, Otentitas Hak-hak Perempuan (Yogyakarta: Fajar Pustaka Baru, 2002), 113.
} 
Untuk itu, dengan berkembangnya ilmu kajian perempuan, gender dan feminisme dalam beberapa gelombang, maka seharusnya perempuan sudah tidak lagi dalam tataran dilema untuk menentukan pilihan ingin keluar ke ranah publik atau tidak. Bahkan, perempuan sudah harus memikirkan bagaimana menunjukkan eksistensi kehidupan dan kualitas perempuan di ruang publik sebagai wujud dan bukti dari ide-ide yang disuarakan selama ini. Perempuan harus mampu menunjukkan bakat, minat, dan kemampuan yang dimilikinya di khalayak luas. Salah satunya dengan menjadi dā'iyah yang berprinsip feminis. Selain itu, dengan Empat prinsip yang ditawarkan oleh Beauvoir dalam mempertahankan eksistensinya, maka dā'iyah di Indonesia akan tetap mampu mempertahankan eksistensinya. Pertama, dā'iyah harus tetap memiliki mental yang kuat untuk bertahan di ruang publik dengan mengaktualisasikan bakat dan minatnya sebagai seorang pendakwah. Kedua, dā'iyah harus selalu menambah kualitas intelektualnya dengan terus mengkaji banyak referensi keilmuan. Seorang dā'iyah harus selalu haus dengan keilmuan sehingga materi dakwah yang disampaikan akan selalu menambah wawasan para jamaahnya. Ketiga, dā'iyah harus selalu bersemangat untuk mencapai transformasi sosial. Artinya, ia harus terus memacu kemampuan dirinya sehingga mampu sejajar bahkan berkompetisi dalam artian positif dengan para pendakwah laki-laki. Keempat, dā'iyah harus selalu menolak dianggap menjadi perempuan nomer dua yang cenderung akan mendomestikasikannya masuk kembali ke dalam rumah, sehingga ia tidak mampu berbuat apa-apa dengan bakat dan kemampuan yang dimilikinya.

\section{F. Kesimpulan}

Dilema yang sering dirasakan oleh dā'iyah dalam memutuskan untuk mengaktualisasikan diri di ranah publik adalah karena peran "motherhood" yang selalu diidentikkan pada figur perempuan shalihah. Hal ini dilegitimasi oleh tafsir agama yang bersifat maskulin dan patriarkat untuk semakin membuat perempuan terdomestikasi. Berbagai upaya telah dilakukan untuk mepertahankan eksistensi seorang dä'iyah dengan melakukan empat strategi: 1) Tetap bertahan untuk mengaktualisasikan diri di ruang publik, 2) Terus menambah kualitas intelektual diri, 3) Terus semangat untuk mencapai trans- 
formasi stratifikasi sosial, dan 4) Tetap menolak untuk dijadikan sebagai makhluk kedua.[s]

\section{Daftar Pustaka}

Ainiyah, Qurrotul. Keadilan Gender dalam Islam. Malang: Intrans Publishing, 2015.

Bandel, Katrin. Kajian Gender dalam Konteks Pascakolonial. Yogyakarta: Sanata Dharma University Press, 2016.

Beauvoir, Simone DE. Second Sex: Fakta dan Mitos. Yogyakarta: Pustaka Promethea, 1989.

Cholil, Mufidah. Psikologi Keluarga Islam Berwawasan Gender. Malang: UIN Maliki Press, 2008.

Jawaad, Haifa A. Otentitas Hak-hak Perempuan. Yogyakarta: Fajar Pustaka Baru, 2002.

Kendall-Tackett, K A, L M Williams, dan D Finkelhor. "Impact of Sexual Abuse on Children: A Review and Synthesis of Recent Empirical Studies." Psychological Bulletin 113, no. 1 (1993): 164-80.

Mulia, Siti Musdah. Muslimah Reformis. Bandung: Mizan Pustaka, 2004.

Saadawi, Nawal El. Perempuan dalam Budaya Patriarki. Yogyakarta: Pustaka Pelajar, 1997.

Tacket, Kathleen Kendall. The Hidden Feelings of Motherhood. Amarillo: Pharmasoft Publishing, 2005.

Tong, Rosemarie P. Feminist Thought: Pengantar Paling Komprehensif kepada Arus Utama Pemikiran Feminis. Yogyakarta: Jalasutra, 1998.

West, Candace, and Don H. Zimmerman. "Doing Gender." Gender and Society 1, no. 2 (1987): 125-51. https://www.gla.ac.uk/0t4/crcees/files/ summerschool/readings/WestZimmerman_1987_DoingGender.pdf. 
This page intentionally left blank 